Elsevier required licence: (c) <2018>. This manuscript version is made available under the CC-BY-NC-ND 4.0 license http://creativecommons.org/licenses/by-nc-nd/4.0/

The definitive publisher version is available online at $h$ ttps://doi.org/10.1016/j.cie.2018.12.026 


\title{
Next Generation Smart Manufacturing and Service Systems using Big Data Analytics
}

\author{
Nagesh Shukla $^{1 *}$, Manoj Kumar Tiwari ${ }^{2}$, Ghassan Beydoun ${ }^{1}$ \\ ${ }^{1}$ School of Information, Systems and Modelling, Faculty of Engineering and Information \\ Technology, University of Technology Sydney, Sydney, Australia 2007. \\ 2 Department of Industrial and Systems Engineering, Indian Institute of Technology, \\ Kharagpur, West Bengal, India 721302 \\ *Corresponding Author: Nagesh.Shukla@uts.edu.au
}

\begin{abstract}
This special issue explores advancements in the next generation manufacturing and service systems by examining the novel methods, practical challenges and opportunities in the use of big data analytics. The selected articles analyse a range of scenarios where big data analytics and its applications were used for improving decision making in manufacturing and services sector such as online data analytics, sourcing decisions with considerations for big data analytics, barriers in the adoption of big data analytics, maintenance planning, and multi-sensor data for fault pattern extraction. The paper summarises the discussions on the use of big data analytics in manufacturing and service sectors.
\end{abstract}

\section{Introduction}

Manufacturing and services industries are now dealing with increasingly massive amount of datasets in short time due to adoption of internet of things (IoT), sensors for asset monitoring, weblogs, social media feeds, product and parts tracking and others (Tien, 2013). Storing big datasets is not new for these industries but gathering actionable and manageable insights from the data is often lacking. This is also termed as 'data rich and information poor'. Big data analytics refers to the capability of organisations for systematic and computational analysis of big data sets, popularly characterised by $5 \mathrm{Vs}$, i.e. volume, velocity, variety, veracity and value adding.

Big data analytics (BDA) has the potential to transform and advance manufacturing and service systems in future. It can help industries in making informed decisions such as better forecast for products, performance management across multiple manufacturing and service units, improving the quality of products and services, providing greater visibility into operations, understanding the customer preferences and buying patterns, real time manufacturing process and asset condition monitoring, product design, customer service and like these others. 
Furthermore, challenges related to supply chain management in service and manufacturing sector have also added to the complexity in presence of big data (Govindan et al., 2018).

Inception of Web 2.0 together with increasing growth in social media and networks has empowered consumers to make better decisions. Differences in product offerings by competing organisations are closed at an increasing pace to win battle for customers (Singh et al., 2018). BDA is also critical to the success of Industry 4.0, a German government initiative, which promotes the integration of IT, manufacturing and operational systems. The benefits of using BDA is enormous but its adoption in many organisations is still in nascent stage.

\section{Literature review on big data analytics in manufacturing systems}

To provide an overview of the topic for this special issue, a broad search in Scopus database was conducted to identify papers published in the area of big data analytics in manufacturing. Keywords such as "big data" and "manufacturing" was selected for the search. Figure 1 illustrates the number of papers published on the topic from 2009 - 2018. In total, there were 1020 papers found after excluding non-English papers.

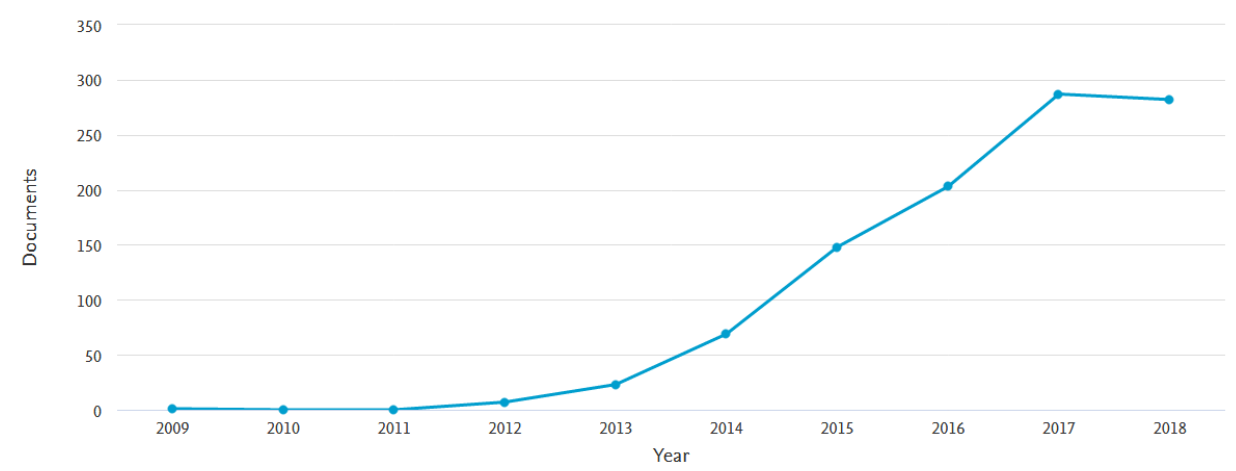

Figure 1: Number of papers published yearly (2009-2018) (as per Scopus)

In terms of journal papers, Procedia CIRP was a leading journal in the area with most contributions on the topic of big data analytics in manufacturing (see Fig 2).

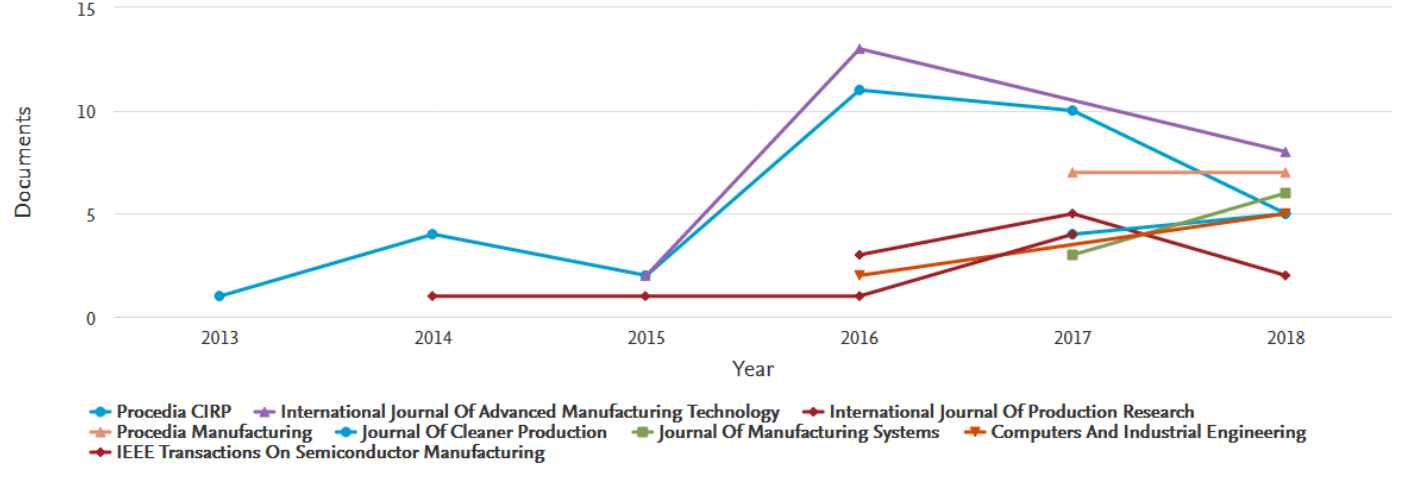

Figure 2: Documents published per year by journals (as per Scopus) 
Upon further investigation into the list of papers found in Scopus database, we obtained the distribution of papers published in various sources. Figure 2 illustrates this distribution. Figure 3 classifies the publications into articles, conference proceeding, book chapters, reviews, books, editorial and others. Figure 4 illustrates the distribution of papers according to the country of origin. Top 10 countries were shown with US occupying the top spot with 242 papers followed by China and Germany with 239 and 87 papers respectively. In terms of subjects areas of these papers, computer science, engineering, decision sciences, mathematics and business management were the top 5 areas (See Fig 5). Further, we have summarised top 20 highly cited papers published on the topic (based on Scopus) in Table 1.

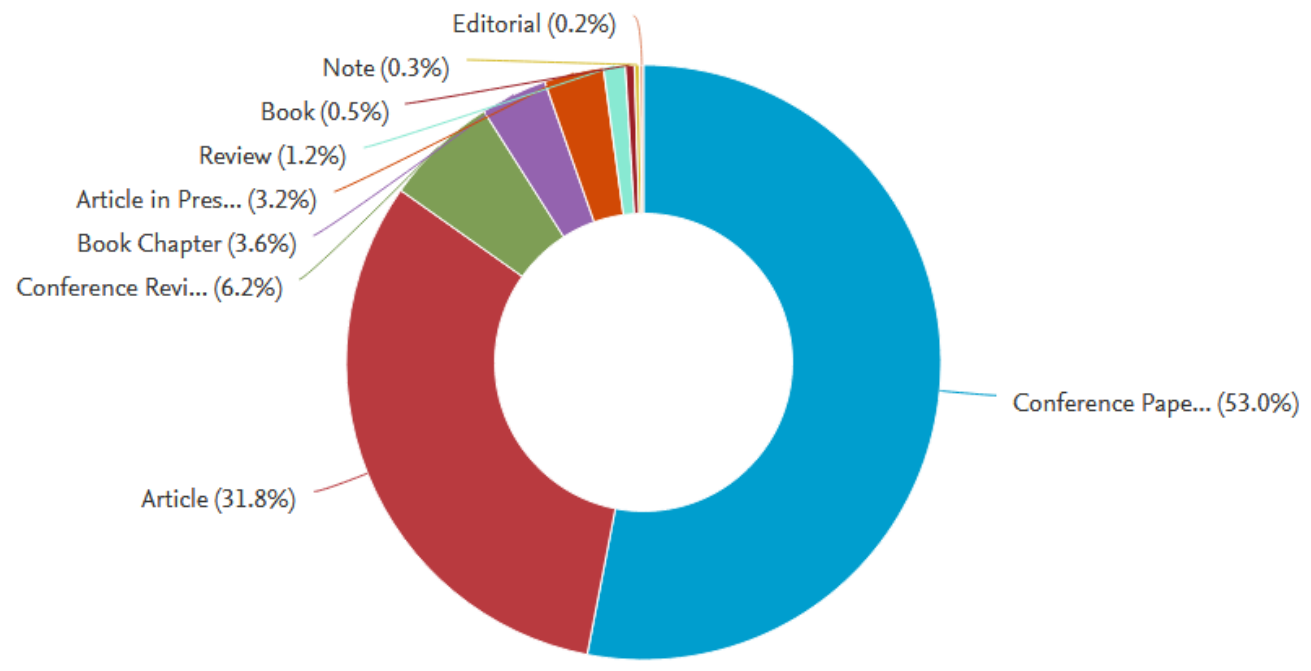

Figure 3: Distribution of papers published on the topic based on Scopus database

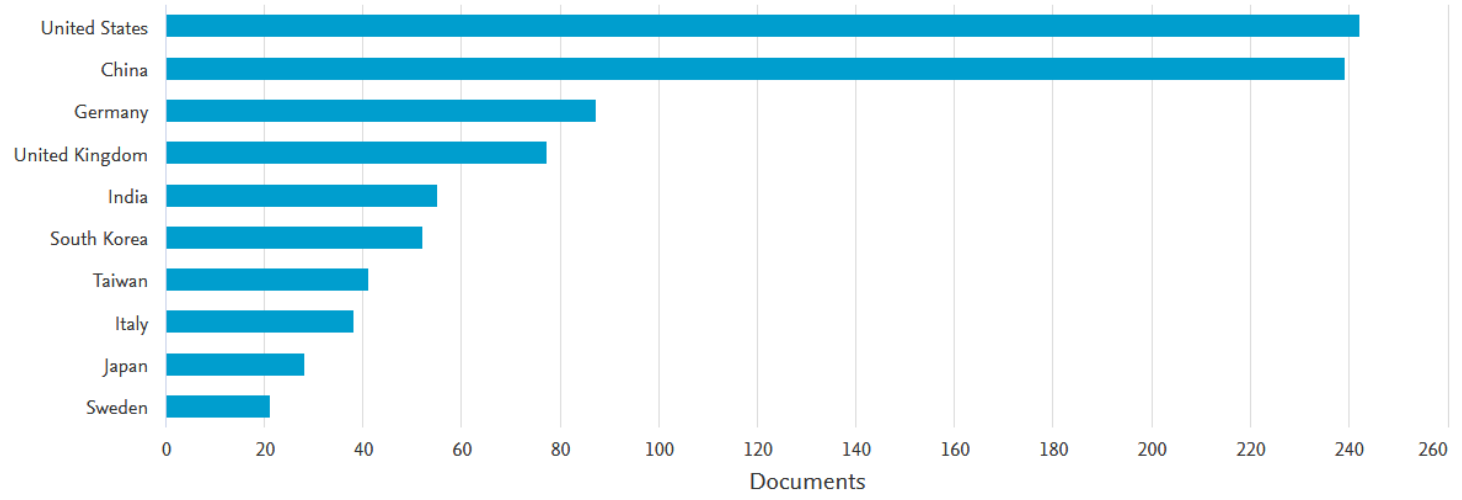

Figure 4: Distribution of papers according to the country of origin based on Scopus database 


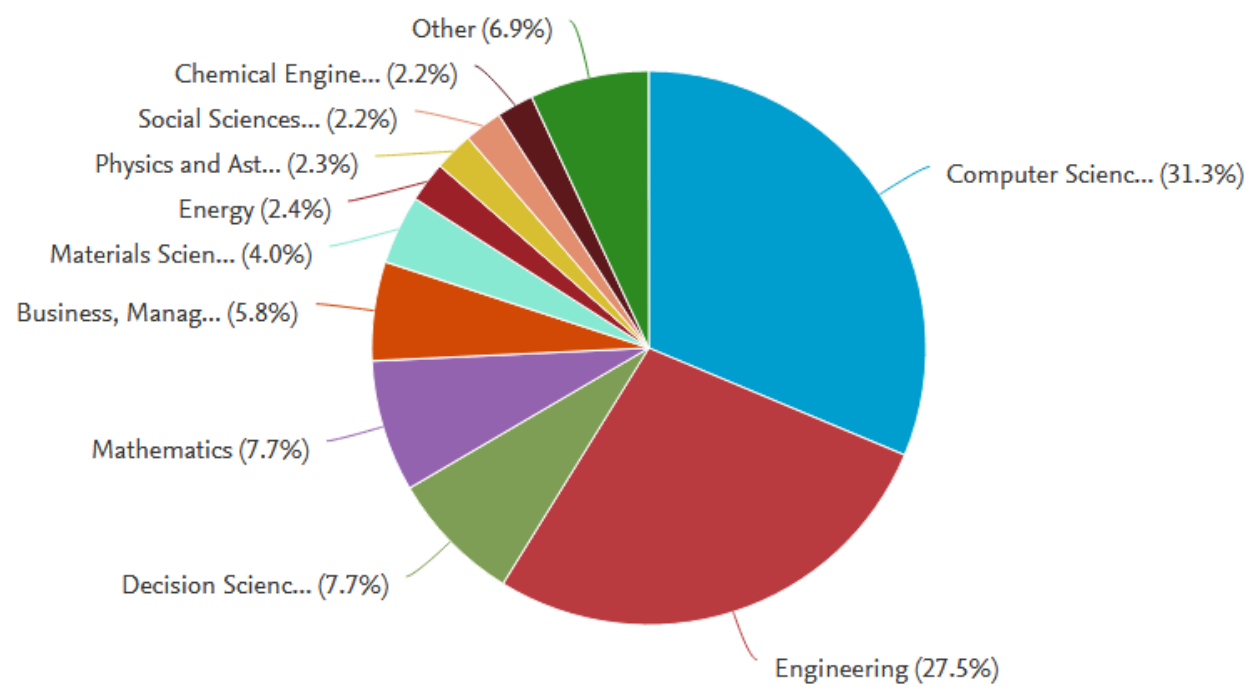

Figure 5: Distribution of papers according to the subject areas as per Scopus database

\section{Papers selected in this special issue}

This special issue focused on publishing original research papers dealing with big data analytics conceptualisation, theoretical knowledge expansion and its real world application in advancing manufacturing or service systems. This issue particularly welcomed papers on the topic of analysing open data or publically available large datasets for improving manufacturing/service operations. Following a rigorous review process, we have selected following research papers to be included into this special issue. The following text introduces these papers.

Dutta et al., (2018) looked at the use of big data analytics in asset liability management and asset allocation in uncertain economic situations using stochastic linear programming (SLP). Issues such as the optimal number of scenarios and its impact on the stability of the model was investigated. It was shown that a stochastic model with fewer scenarios resulted in higher improvements in both return side measures as well as risk side measures in comparison with a mean value model or a partial mean value model. An experimental design was also presented to test the relevance of the proposed model.

Srinivas and Rajendran, (2018) focussed on the growing problem of decline in University enrolments and retention rates. With the inception of Web 2.0 and increased information availability, students are making informed choices regarding university education. This paper used online student reviews together with advances text analytics to identify the current strengths, weaknesses, opportunities and threats (SWOT) of a university. Their approach included an ensemble of Latent Dirichlet Allocation (E-LDA) topic models to identify topics that are predominantly discussed in the online reviews and categorize each review sentence into the most related topic. Then a sentiment analysis was conducted followed by a topic-based opinion summary (TOS) analysis for a university. A case study was used to highlight the applicability of proposed research to improve university recruitment and retention policy and procedures. 
Table 1: Top 20 highly cited papers on the topic from Scopus

\begin{tabular}{|c|c|c|c|c|c|}
\hline Reference & Title & Problem Addressed & Methodology used & Article Type & $\begin{array}{l}\text { Cited } \\
\text { (Scopus) }\end{array}$ \\
\hline $\begin{array}{l}\text { Lee et al., } \\
(2014)\end{array}$ & $\begin{array}{l}\text { Service innovation and } \\
\text { smart analytics for Industry } \\
4.0 \text { and big data } \\
\text { environment }\end{array}$ & $\begin{array}{l}\text { Discussed the trends of manufacturing } \\
\text { service transformation in big data } \\
\text { environment, as well as the readiness } \\
\text { of smart predictive informatics tools } \\
\text { to manage big data }\end{array}$ & Survey of the area and analysis of trends & Conceptual & 313 \\
\hline $\begin{array}{l}\text { Cohen et al., } \\
(2009)\end{array}$ & $\begin{array}{l}\text { MAD skills: New analysis } \\
\text { practices for big data }\end{array}$ & $\begin{array}{l}\text { Highlighted the use of emerging } \\
\text { Magnetic, Agile, Deep (MAD) data } \\
\text { analysis and its comparison against } \\
\text { traditional Enterprise Data } \\
\text { Warehouses and Business Intelligence }\end{array}$ & Overview of MAD and its applicability & Conceptual & 267 \\
\hline $\begin{array}{l}\text { Lee et al., } \\
(2013)\end{array}$ & $\begin{array}{l}\text { Recent advances and trends } \\
\text { in predictive manufacturing } \\
\text { systems in big data } \\
\text { environment }\end{array}$ & $\begin{array}{l}\text { Analysed recent trends in predictive } \\
\text { manufacturing systems in big data } \\
\text { scenario }\end{array}$ & Conceptual overview of the area & Conceptual & 230 \\
\hline $\begin{array}{l}\text { Wang et al., } \\
(2016 a)\end{array}$ & $\begin{array}{l}\text { Implementing Smart } \\
\text { Factory of Industrie 4.0: } \\
\text { An Outlook }\end{array}$ & $\begin{array}{l}\text { A framework and operational } \\
\text { mechanism to implement flexible and } \\
\text { reconfigurable smart factory }\end{array}$ & Framework development & Framework & 179 \\
\hline Li et al., (2015) & $\begin{array}{l}\text { Big Data in product } \\
\text { lifecycle management }\end{array}$ & $\begin{array}{l}\text { Applications of Big Data in product } \\
\text { lifecycle management are summarised } \\
\text { and future application areas are } \\
\text { identified }\end{array}$ & $\begin{array}{l}\text { Review of literature on big data use for product } \\
\text { lifecycle management }\end{array}$ & Survey & 159 \\
\hline $\begin{array}{l}\text { Zhong et al., } \\
(2015)\end{array}$ & $\begin{array}{l}\text { A big data approach for } \\
\text { logistics trajectory } \\
\text { discovery from RFID- } \\
\text { enabled production data }\end{array}$ & $\begin{array}{l}\text { Introduces a holistic big data approach } \\
\text { to excavate frequent trajectory from } \\
\text { massive RFID-enabled shopfloor } \\
\text { logistics data }\end{array}$ & $\begin{array}{l}\text { Proposed a big data approach for mining the } \\
\text { invaluable trajectory knowledge from } \\
\text { enormous RFID-enabled logistics data }\end{array}$ & Modelling & 123 \\
\hline $\begin{array}{l}\text { Kang et al., } \\
(2016)\end{array}$ & $\begin{array}{l}\text { Smart manufacturing: Past } \\
\text { research, present findings, } \\
\text { and future directions }\end{array}$ & $\begin{array}{l}\text { Surveyed and analyzed various } \\
\text { articles related to Smart } \\
\text { Manufacturing }\end{array}$ & $\begin{array}{l}\text { Review of literature on smart manufacturing } \\
\text { including Industry } 4.0, \text { smart factory, cuber- } \\
\text { physical system, internet of things and big data }\end{array}$ & Survey & 125 \\
\hline $\begin{array}{l}\text { Wan et al., } \\
(2016)\end{array}$ & $\begin{array}{l}\text { Software-Defined } \\
\text { Industrial Internet of } \\
\text { Things in the Context of } \\
\text { Industry } 4.0\end{array}$ & $\begin{array}{l}\text { Proposed a new concept for industrial } \\
\text { environments by introducing } \\
\text { software-defined industrial IoT to } \\
\text { make the network more flexible }\end{array}$ & $\begin{array}{l}\text { Proposed a software-defined industrial IoT } \\
\text { architecture to manage physical devices and } \\
\text { provide an interface for information exchange }\end{array}$ & $\begin{array}{l}\text { Framework/ } \\
\text { IoT } \\
\text { Architecture }\end{array}$ & 108 \\
\hline
\end{tabular}




\begin{tabular}{|c|c|c|c|c|c|}
\hline Chae, (2015) & $\begin{array}{l}\text { Insights from hashtag } \\
\text { \#supplychain and Twitter } \\
\text { analytics: Considering } \\
\text { Twitter and Twitter data } \\
\text { for supply chain practice } \\
\text { and research }\end{array}$ & $\begin{array}{l}\text { Proposed a novel, analytical } \\
\text { framework (Twitter Analytics) for } \\
\text { analysing supply chain tweets, } \\
\text { highlighting the current use of Twitter } \\
\text { in supply chain contexts }\end{array}$ & $\begin{array}{l}\text { Descriptive analytics (DA), Content analytics } \\
\text { (CA) integrating text mining and sentiment } \\
\text { analysis, and network analytics (NA) }\end{array}$ & $\begin{array}{l}\text { Data } \\
\text { Modelling } \\
\text { and } \\
\text { Framework }\end{array}$ & 98 \\
\hline $\begin{array}{l}\text { Opresnik and } \\
\text { Taisch, (2015) }\end{array}$ & $\begin{array}{l}\text { The value of big data in } \\
\text { servitization }\end{array}$ & $\begin{array}{l}\text { Proposed a new basis for competitive } \\
\text { advantage for manufacturing } \\
\text { enterprises called a Big Data Strategy } \\
\text { in Servitization and scrutinized how } \\
\text { manufacturers can exploit the } \\
\text { opportunity arising from combined } \\
\text { Big Data and servitization }\end{array}$ & Conceptual simulation & Conceptual & 99 \\
\hline $\begin{array}{l}\text { Loebbecke and } \\
\text { Picot, (2015) }\end{array}$ & $\begin{array}{l}\text { Reflections on societal and } \\
\text { business model } \\
\text { transformation arising from } \\
\text { digitization and big data } \\
\text { analytics: A research } \\
\text { agenda }\end{array}$ & $\begin{array}{l}\text { Outlined a research agenda on how } \\
\text { digitization and big data analytics } \\
\text { drive the transformation of business } \\
\text { and society together with highlighting } \\
\text { the impact of digitization and big data } \\
\text { analytics on employment }\end{array}$ & $\begin{array}{l}\text { Reflections on changes in societal and business } \\
\text { model due to digitization and big data analytics }\end{array}$ & $\begin{array}{l}\text { Research } \\
\text { Agenda }\end{array}$ & 97 \\
\hline Tien, (2013) & $\begin{array}{l}\text { Big Data: Unleashing } \\
\text { information }\end{array}$ & $\begin{array}{l}\text { Proposed critical observations with } \\
\text { regard to big data both its benefits } \\
\text { and concerns/challenges }\end{array}$ & Broad review & $\begin{array}{l}\text { Critical } \\
\text { review }\end{array}$ & 83 \\
\hline $\begin{array}{l}\text { Wang et al., } \\
(2016 \mathrm{~b})\end{array}$ & $\begin{array}{l}\text { Towards smart factory for } \\
\text { industry 4.0: A self- } \\
\text { organized multi-agent } \\
\text { system with big data based } \\
\text { feedback and coordination }\end{array}$ & $\begin{array}{l}\text { Proposed a smart factory framework } \\
\text { which comprise of industrial network, } \\
\text { cloud, and supervisory control } \\
\text { terminals with smart shop-floor } \\
\text { objects such as machines, conveyers, } \\
\text { and products }\end{array}$ & $\begin{array}{l}\text { A self-organized multi-agent system supported } \\
\text { by big data based feedback and coordination }\end{array}$ & $\begin{array}{l}\text { Framework } \\
\text { and } \\
\text { Simulation } \\
\text { Modelling }\end{array}$ & 95 \\
\hline $\begin{array}{l}\text { Tao et al., } \\
(2015)\end{array}$ & $\begin{array}{l}\text { Manufacturing Service } \\
\text { Management in Cloud } \\
\text { Manufacturing: Overview } \\
\text { and Future Research } \\
\text { Directions }\end{array}$ & $\begin{array}{l}\text { Summarises existing works and } \\
\text { technologies on manufacturing service } \\
\text { management in cloud manufacturing }\end{array}$ & $\begin{array}{l}\text { Conceptual overview paper with future } \\
\text { research directions are identified and discussed }\end{array}$ & Survey & 81 \\
\hline $\begin{array}{l}\text { Babiceanu and } \\
\text { Seker, (2016) }\end{array}$ & $\begin{array}{l}\text { Big Data and virtualization } \\
\text { for manufacturing cyber- } \\
\text { physical systems: A survey } \\
\text { of the current status and } \\
\text { future outlook }\end{array}$ & $\begin{array}{l}\text { Provides overview of the current } \\
\text { status of virtualization and cloud- } \\
\text { based services for manufacturing } \\
\text { systems and of the use of Big Data }\end{array}$ & State-of-the-art review & $\begin{array}{l}\text { Survey and } \\
\text { Framework }\end{array}$ & 80 \\
\hline
\end{tabular}




\begin{tabular}{|c|c|c|c|c|c|}
\hline & & $\begin{array}{l}\text { analytics for planning and control of } \\
\text { manufacturing operations }\end{array}$ & & & \\
\hline $\begin{array}{l}\text { Dutta and Bose, } \\
(2015)\end{array}$ & $\begin{array}{l}\text { Managing a big data } \\
\text { project: The case of Ramco } \\
\text { cements limited }\end{array}$ & $\begin{array}{l}\text { A new framework for implementing } \\
\text { Big Data analytics projects is } \\
\text { proposed }\end{array}$ & $\begin{array}{l}\text { A new framework based on conceptualizing, } \\
\text { planning and successfully implementing Big } \\
\text { Data projects }\end{array}$ & $\begin{array}{l}\text { Framework } \\
\text { and Industry } \\
\text { Implementati } \\
\text { on }\end{array}$ & 76 \\
\hline $\begin{array}{l}\text { Pääkkönen and } \\
\text { Pakkala, (2015) }\end{array}$ & $\begin{array}{l}\text { Reference Architecture and } \\
\text { Classification of } \\
\text { Technologies, Products and } \\
\text { Services for Big Data } \\
\text { Systems }\end{array}$ & $\begin{array}{l}\text { Proposed a technology independent } \\
\text { reference architecture for big data } \\
\text { systems }\end{array}$ & Reference architecture for big data systems & $\begin{array}{l}\text { Architecture } \\
\text { for Big data } \\
\text { systems }\end{array}$ & 75 \\
\hline $\begin{array}{l}\text { Zhong et al., } \\
(2016)\end{array}$ & $\begin{array}{l}\text { Big Data for supply chain } \\
\text { management in the service } \\
\text { and manufacturing sectors: } \\
\text { Challenges, opportunities, } \\
\text { and future perspectives }\end{array}$ & $\begin{array}{l}\text { A state-of-the-art research on big data } \\
\text { in supply chain management in } \\
\text { service and manufacturing sectors is } \\
\text { reviewed }\end{array}$ & State-of-the-art review & Survey & 73 \\
\hline $\begin{array}{l}\text { Dubey et al., } \\
(2016)\end{array}$ & $\begin{array}{l}\text { The impact of big data on } \\
\text { world-class sustainable } \\
\text { manufacturing }\end{array}$ & $\begin{array}{l}\text { Studied the impact of big data } \\
\text { analytics in supporting world-class } \\
\text { sustainable manufacturing }\end{array}$ & $\begin{array}{l}\text { Analysis of survey responses from senior } \\
\text { managers }\end{array}$ & $\begin{array}{l}\text { Conceptual } \\
\text { framework }\end{array}$ & 66 \\
\hline $\begin{array}{l}\text { Waller and } \\
\text { Fawcett, (2013) }\end{array}$ & $\begin{array}{l}\text { Click here for a data } \\
\text { scientist: Big data, } \\
\text { predictive analytics, and } \\
\text { theory development in the } \\
\text { era of a maker movement } \\
\text { supply chain }\end{array}$ & $\begin{array}{l}\text { Proposed a } 2 \times 2 \text { model to explain the } \\
\text { role of predictive analytics in the } \\
\text { theory development process }\end{array}$ & Conceptual & $\begin{array}{l}\text { Review of } \\
\text { the literature }\end{array}$ & 58 \\
\hline
\end{tabular}

Baek and Kim, (2018) focussed on the developing a data analytic technique for identifying significant sensor signals for detecting faults in the manufacturing systems. The abrupt variance and the discernibility index of multi-sensor signals was analysed by extending the conventional statistical variance and the Fisher criterion for better performances. Based on the sensor signals, a set of most significant sensors were selected to detect abnormal cylinder temperature and engine knocking. This research illustrated that an improved detection results can be obtained when the multi-sensor signals in multiple overlapping regions was present regardless of the operational states. 
Kumar et al., (2018) looked at the use of big data tools for conditioned based maintenance in manufacturing systems. An approach for health state estimation to facilitate autonomous diagnostics was developed using a polynomial regression models. In particular, a model based sequential clustering on time series sensor signals for estimating health states of a cutting tool. The results of the model validates the performances of method on a CNC machining test-bed equipped with sensors.

Shukla and Mattar, (2018) proposed an approach for smart sustainable auditing systems. It aims to identify the critical barriers and their dynamic interrelations in the application of big data analytics (BDA) based smart sustainable auditing system. An Interpretive Structural Modelling (ISM) approach was used to model BDA adoption barriers and their relationships. The results provide users with guidelines to prioritise the interventions to facilitate the adoption of BDA in the sustainable auditing systems.

Alkahtani et al., (2018) proposed a decision support system which relied on the ontology and data mining approaches with a view to improve quality of products whilst minimizing warranty costs. This study involved integrating ontology-based text mining, self-organizing maps, reliability and cost optimization to identify manufacturing faults. The warranty data was effectively mapped to the design information, which was ultimately used for optimising design parameters for better reliability, and reduced cost. Warranty database comprised of textual data obtained from customers. An ontology-based text mining was used to identify hidden knowledge in these datasets. Then a Self-Organizing Maps (SOM) was used to relate the information gathered through warranty database to the manufacturing datasets. In the final step, optimal values of design parameters were obtained by identifying areas where improvements have resulted in the highest reliability for the lowest cost.

Lamba et al., (2018) proposed a mixed-integer nonlinear program (MINLP) for supplier selection considering optimal lot-sizes in multi-periods and multi-products setting. The overall objection of this formulation and solution procedure was to reduce overall supply chain cost as well as associated cost of carbon emissions. The model used parameters involving different dimensions of Big Data (volume, velocity and variety). The model was validated with a set of simulated datasets comprising of essential parameters based on big data analytics.

Cui et al., (2018) analysed the impact of a free trade agreement (FTA) among China, Japan, and South Korea using big data analytics. The study involved game theory and the computable general equilibrium approach. The findings illustrate that FTA with agricultural protection not only stimulates economic growth in the three countries but also reduces Japan and South Korea's agricultural concerns and impact on employment. In addition, it indicates that China will increase imports of energy-intensive products from Japan and South Korea, which may reduce domestic output and generate environmental benefits. It was highlighted from the study that the trilateral FTA with agricultural protection may reduce carbon emission in Northeast Asia by 6.53 million tons.

Moktadir et al., (2018) investigated the barriers in application of big data analytics in manufacturing supply chains in the context of Bangladesh. A comprehensive set of barriers 
related to big data and big data analytics was identified and examined using a Delphi-based analytic hierarchy process (AHP) together with a sensitivity analysis to justify robustness of the barrier rankings. An empirical dataset from five Bangladeshi manufacturing firms were used in this study. The results of this study highlighted key barriers in big data adoption in manufacturing supply chains in Bangladesh. The results can help managers to understand critical barriers and potential benefits of using BDA in manufacturing supply chains.

Dev et al., (2018) proposed a big data architecture (BDA) for key performance indicators (KPI) data of a supply chain. The conceptual framework is proposed under RFID integrated with cloud based ERP systems. Within the big data analytics framework, the model was highlighted to be useful as a decision support tool to help companies to evaluate their KPIs in a real-time dynamic system. The study attempts to (i) construct a bridge between discrete event simulation and big data analytics (ii) provide a novel method for the pairwise comparison within the clusters and among different clusters for ANP is determined through a simple heuristic method, and (iii) extends the studies on evaluating the KPIs in a real-time by including the role of predictive analytics.

Liu, (2018) proposed a novel Chinese text classification model for the project management office using fuzzy semantics and text mining techniques. In first step of this methodology, a content analysis was used to convert important textual information and compiled it into a keyword index. In the following step, a customer classification and decision algorithm for grey fuzzy situations was developed to categorize the textual data. In the final step, an effective marketing strategy was formulated to target the various customer combinations, growth models, and the best modes of service. A real database of a company was used to highlight the implementation of the proposed approach.

Verma et al., (2018) proposed a big data approach for detecting households with Plug-in Electric Vehicles (PEVs) and to provide customized PEV charging incentives to managing imbalance in the grid system. The utility industry has strong motivation to provide extra demand due to PEVs in off-peak hours. The big data analysis method proposed in this paper used high frequency advanced metering infrastructure (AMI) data obtained from a large-scale utility company in Midwest USA. The results achieved an accuracy of $80 \%$ or more in successfully detecting households with PEVs.

Srinivasan et al., (2018) introduced a novel approach to investigate the impact of climate change on food sourcing decisions. In particular, the impact of environmental changes on the suitability of different regions in terms of growing certain food items has been assessed. A three-stage approach was proposed to guide food sourcing decisions by incorporating climate change data. Uncertainties in climate change are modelled using range of publicly available datasets to calculate the suitability and risk indices associated with growing a crop in a particular geographical area. Results from a case study illustrates that sourcing decisions of popular food items are likely to require significant adaptations due to changes to the suitability of certain regions. 
Dinis et al., (2018) focused on Bayesian networks based capacity planning problem faced by aircraft Maintenance, Repair and Overhaul (MRO) companies. A Bayesian networks as a predictive big data tool was used to manage the uncertainty in the maintenance workloads and to improve the capacity planning decision-making in presence of incomplete information. A real industrial dataset referring to aircraft maintenance projects of a Portuguese MRO was used to develop Bayesian networks. The benefits of big data analytics tool in aircraft maintenance were demonstrated through examples referring to capacity planning and sales planning.

Fahmideh and Beydoun, (2018) proposed an approach for goal-obstacle analysis and selecting suitable big data solution architectures that satisfy preferences and constraints of stakeholders in presence of the decision outcome uncertainty. The approach employs goal-oriented modelling and fuzzy logic to identify obstacles causing quality goal failures and to find an optimal set of architectural decisions for the big data enablement process in manufacturing systems. The effectiveness of the proposed approach was highlighted via reengineering a hyper-connected manufacturing collaboration system to a new big data architecture.

Tewari and Dwivedi, (2018) explored a big data-driven ensemble learning for a petroleum reservoir development and characterization problem. The problem involved detection and recognition of underlying subsurface rock's lithofacies. This study employed the real-time well-logs data collected from variety of sensing tools. The proposed methodology used ensemble technique to combine diverse opinions of experts to obtain overall prediction decisions. The proposed big data analytics includes development and comparative performances of popular ensemble methods such as Bagging, AdaBoost, Rotation forest, Random subspace, and DECORATE. Comparative analysis was conducted on the Kansas (U.S.A.) oil-field data and the supremacy of proposed method over the existing techniques used for quantitative lithofacies modelling was established.

\section{Conclusion}

Finally, the application of big data analytics in advancing the knowledge in manufacturing and service sectors is growing rapidly and selected papers highlight some of the innovative applications in this area.

We are happy to guest edit this special issue and we believe that the papers selected in this special issue will advance our understanding of next generation manufacturing and service systems with the help of big data analytics-based approaches. We would like to thank Professor Mohamed Dessouky and Professor Yasser Dessouky, editors of Computers \& Industrial Engineering, for accepting our special issue proposal. We extend our sincere thanks and appreciation to all contributors and anonymous referees for their valuable time and efforts in the review process.

\section{References:}

ALKAHTANI, M., CHOUDHARY, A., DE, A. \& HARDING, J. A. 2018. A decision support system based on ontology and data mining to improve design using warranty data. Computers \& Industrial Engineering. 
BABICEANU, R. F. \& SEKER, R. 2016. Big Data and virtualization for manufacturing cyber-physical systems: A survey of the current status and future outlook. Computers in Industry, 81, 128-137.

BAEK, S. \& KIM, D.-Y. 2018. Abrupt variance and discernibility analyses of multi-sensor signals for fault pattern extraction. Computers \& Industrial Engineering.

CHAE, B. 2015. Insights from hashtag \#supplychain and Twitter Analytics: Considering Twitter and Twitter data for supply chain practice and research. International Journal of Production Economics, 165, 247-259.

COHEN, J., DOLAN, B., DUNLAP, M., HELLERSTEIN, J. M. \& WELTON, C. 2009. MAD skills: new analysis practices for big data. Proc. VLDB Endow., 2, 1481-1492.

CUI, L., SONG, M. \& ZHU, L. 2018. Economic evaluation of the trilateral FTA among China, Japan, and South Korea with big data analytics. Computers \& Industrial Engineering.

DEV, N. K., SHANKAR, R., GUPTA, R. \& DONG, J. 2018. Multi-criteria evaluation of real-time key performance indicators of supply chain with consideration of big data architecture. Computers \& Industrial Engineering.

DINIS, D., BARBOSA-PÓVOA, A. \& TEIXEIRA, Â. P. 2018. Valuing data in aircraft maintenance through big data analytics: A probabilistic approach for capacity planning using Bayesian networks. Computers \& Industrial Engineering.

DUBEY, R., GUNASEKARAN, A., CHILDE, S. J., WAMBA, S. F. \& PAPADOPOULOS, T. 2016. The impact of big data on world-class sustainable manufacturing. The International Journal of Advanced Manufacturing Technology, 84, 631-645.

DUTTA, D. \& BOSE, I. 2015. Managing a Big Data project: The case of Ramco Cements Limited. International Journal of Production Economics, 165, 293-306.

DUTTA, G., RAO, H. V., BASU, S. \& TIWARI, M. K. 2018. Asset liability management model with decision support system for life insurance companies: Computational results. Computers \& Industrial Engineering.

FAHMIDEH, M. \& BEYDOUN, G. 2018. Big data analytics architecture design-An application in manufacturing systems. Computers \& Industrial Engineering.

GOVINDAN, K., CHENG, T. C. E., MISHRA, N. \& SHUKLA, N. 2018. Big data analytics and application for logistics and supply chain management. Transportation Research Part E: Logistics and Transportation Review, 114, 343-349.

KANG, H. S., LEE, J. Y., CHOI, S., KIM, H., PARK, J. H., SON, J. Y., KIM, B. H. \& NOH, S. D. 2016. Smart manufacturing: Past research, present findings, and future directions. International Journal of Precision Engineering and Manufacturing-Green Technology, 3, 111-128.

KUMAR, A., CHINNAM, R. B. \& TSENG, F. 2018. An HMM and polynomial regression based approach for remaining useful life and health state estimation of cutting tools. Computers \& Industrial Engineering.

LAMBA, K., SINGH, S. P. \& MISHRA, N. 2018. Integrated decisions for supplier selection and lotsizing considering different carbon emission regulations in Big Data environment. Computers \& Industrial Engineering.

LEE, J., KAO, H.-A. \& YANG, S. 2014. Service Innovation and Smart Analytics for Industry 4.0 and Big Data Environment. Procedia CIRP, 16, 3-8.

LEE, J., LAPIRA, E., BAGHERI, B. \& KAO, H.-A. 2013. Recent advances and trends in predictive manufacturing systems in big data environment. Manufacturing Letters, 1, 38-41.

LI, J., TAO, F., CHENG, Y. \& ZHAO, L. 2015. Big Data in product lifecycle management. The International Journal of Advanced Manufacturing Technology, 81, 667-684.

LIU, J.-W. 2018. Using big data database to construct new GFuzzy text mining and decision algorithm for targeting and classifying customers. Computers \& Industrial Engineering.

LOEBBECKE, C. \& PICOT, A. 2015. Reflections on societal and business model transformation arising from digitization and big data analytics: A research agenda. The Journal of Strategic Information Systems, 24, 149-157.

MOKTADIR, M. A., ALI, S. M., PAUL, S. K. \& SHUKLA, N. 2018. Barriers to big data analytics in manufacturing supply chains: A case study from Bangladesh. Computers \& Industrial Engineering.

OPRESNIK, D. \& TAISCH, M. 2015. The value of Big Data in servitization. International Journal of Production Economics, 165, 174-184. 
PÄÄKKÖNEN, P. \& PAKKALA, D. 2015. Reference Architecture and Classification of Technologies, Products and Services for Big Data Systems. Big Data Research, 2, 166-186.

SHUKLA, M. \& MATTAR, L. 2018. Next generation smart sustainable auditing systems using Big Data Analytics: Understanding the interaction of critical barriers. Computers \& Industrial Engineering.

SINGH, A., SHUKLA, N. \& MISHRA, N. 2018. Social media data analytics to improve supply chain management in food industries. Transportation Research Part E: Logistics and Transportation Review, 114, 398-415.

SRINIVAS, S. \& RAJENDRAN, S. 2018. Topic-based knowledge mining of online student reviews for strategic planning in universities. Computers \& Industrial Engineering.

SRINIVASAN, R., GIANNIKAS, V., KUMAR, M., GUYOT, R. \& MCFARLANE, D. 2018. Modelling food sourcing decisions under climate change: A data-driven approach. Computers \& Industrial Engineering.

TAO, F., ZHANG, L., LIU, Y., CHENG, Y., WANG, L. \& XU, X. 2015. Manufacturing Service Management in Cloud Manufacturing: Overview and Future Research Directions. Journal of Manufacturing Science and Engineering, 137, 040912-040912-11.

TEWARI, S. \& DWIVEDI, U. D. 2018. Ensemble-based big data analytics of lithofacies for automatic development of petroleum reservoirs. Computers \& Industrial Engineering.

TIEN, J. M. 2013. Big Data: Unleashing information. Journal of Systems Science and Systems Engineering, 22, 127-151.

VERMA, A., ASADI, A., YANG, K., MAITRA, A. \& ASGEIRSSON, H. 2018. Analyzing household charging patterns of Plug-in electric vehicles (PEVs): A data mining approach. Computers \& Industrial Engineering.

WALLER, M. A. \& FAWCETT, S. E. 2013. Click Here for a Data Scientist: Big Data, Predictive Analytics, and Theory Development in the Era of a Maker Movement Supply Chain. Journal of Business Logistics, 34, 249-252.

WAN, J., TANG, S., SHU, Z., LI, D., WANG, S., IMRAN, M. \& VASILAKOS, A. V. 2016. SoftwareDefined Industrial Internet of Things in the Context of Industry 4.0. IEEE Sensors Journal, 16, 7373-7380.

WANG, S., WAN, J., LI, D. \& ZHANG, C. 2016a. Implementing Smart Factory of Industrie 4.0: An Outlook. International Journal of Distributed Sensor Networks, 12, 3159805.

WANG, S., WAN, J., ZHANG, D., LI, D. \& ZHANG, C. 2016b. Towards smart factory for industry 4.0: a self-organized multi-agent system with big data based feedback and coordination. Computer Networks, 101, 158-168.

ZHONG, R. Y., HUANG, G. Q., LAN, S., DAI, Q. Y., CHEN, X. \& ZHANG, T. 2015. A big data approach for logistics trajectory discovery from RFID-enabled production data. International Journal of Production Economics, 165, 260-272.

ZHONG, R. Y., NEWMAN, S. T., HUANG, G. Q. \& LAN, S. 2016. Big Data for supply chain management in the service and manufacturing sectors: Challenges, opportunities, and future perspectives. Computers \& Industrial Engineering, 101, 572-591. 